University of Nebraska - Lincoln

DigitalCommons@University of Nebraska - Lincoln

USGS Staff -- Published Research

US Geological Survey

2012

\title{
Gonadal abnormalities in frogs (Lithobates spp.) collected from managed wetlands in an agricultural region of Nebraska, USA
}

Diana M. Papoulias

U.S. Geological Survey, dpapoulias@usgs.gov

Matt S. Schwarz

Nebraska Ecological Services Field Office, matt_schwarz@fws.gov

Lourdes Mena

Nebraska Ecological Services Field Office, lourdes_mena@fws.gov

Follow this and additional works at: http:// digitalcommons.unl.edu/usgsstaffpub

Part of the Geology Commons, Oceanography and Atmospheric Sciences and Meteorology Commons, Other Earth Sciences Commons, and the Other Environmental Sciences Commons

Papoulias, Diana M.; Schwarz, Matt S.; and Mena, Lourdes, "Gonadal abnormalities in frogs (Lithobates spp.) collected from managed wetlands in an agricultural region of Nebraska, USA" (2012). USGS Staff-- Published Research. 933.

http:// digitalcommons.unl.edu/usgsstaffpub/933

This Article is brought to you for free and open access by the US Geological Survey at DigitalCommons@University of Nebraska - Lincoln. It has been accepted for inclusion in USGS Staff -- Published Research by an authorized administrator of DigitalCommons@University of Nebraska - Lincoln. 


\title{
Gonadal abnormalities in frogs (Lithobates spp.) collected from managed wetlands in an agricultural region of Nebraska, USA
}

\author{
Diana M. Papoulias ${ }^{\mathrm{a}, *}$, Matt S. Schwarz ${ }^{\mathrm{b}, 1}$, Lourdes Mena ${ }^{\mathrm{b}}$ \\ ${ }^{a}$ Columbia Environmental Research Center, U.S. Geological Survey, 4200 New Haven Rd., Columbia, MO 65201, USA \\ ${ }^{\mathrm{b}}$ U.S. Fish and Wildlife Service, Nebraska Ecological Services Field Office, 203 W 2nd St., Grand Island, NE 68801, USA
}

\section{A R T I C L E I N F O}

\section{Article history:}

Received 24 February 2012

Received in revised form

6 July 2012

Accepted 25 July 2012

\section{Keywords:}

Ecotoxicology

Pesticides

Rainwater Basin

Endocrine disruption

Amphibian sexual development

\begin{abstract}
A B S T R A C T
Nebraska's Rainwater Basin (RWB) provides important wetland habitat for North American migratory birds. Concern exists that pesticide and nutrient runoff from surrounding row-crops enters wetlands degrading water quality and adversely affecting birds and wildlife. Frogs may be especially vulnerable. Plains leopard (Lithobates blairi) metamorphs from RWB wetlands with varying concentrations of pesticides were evaluated for a suite of biomarkers of exposure to endocrine active chemicals. Froglets had ovarian dysgenesis, high rates of testicular oocytes, and female-biased sex ratios however, there was no clear statistical association between pesticide concentrations and biomarkers. Data interpretation was hindered because timing and duration of exposures were unknown and due to an incomplete understanding of $L$. blairi sexual development. Emphasis is on describing the complex developmental biology of closely-related leopard frogs, how this understanding can explain RWB L. blairi anomalies, and the need for sampling at the appropriate life stage.
\end{abstract}

Published by Elsevier Ltd.

\section{Introduction}

The Rainwater Basin (RWB) was once an extensive playa complex with over 3900 wetlands distributed over 4200 square miles of south-central Nebraska (Schildman and Hurt, 1984). Located prominently within a major north-south migration corridor, the Central Flyway, it is annually visited by millions of waterfowl and shorebirds (RWBJV, 2012, Fig. 1). During spring migration, the RWB hosts approximately $90 \%$ of the mid-continent population of greater white-fronted geese (Ansu albiforns), $50 \%$ of the mid-continent population of mallards (Anas platyrhynchos), and $30 \%$ of the continental population of northern pintails (Anas acuta) (Benning, 1987; Bortner et al., 1991). The threatened and endangered whooping crane (Grus americana) and piping plover (Charadrius melodus) also use RWB wetlands. Recognizing the importance of the RWB to healthy waterfowl populations, in 1963 the U.S. Fish and Wildlife Service (USFWS) began managing 61 waterfowl production areas (WPA) (USFWS, 2011). Although primarily for

\footnotetext{
* Corresponding author.

E-mail addresses: dpapoulias@usgs.gov (D.M. Papoulias), matt_schwarz@ fws.gov (M.S. Schwarz), lourdes_mena@fws.gov (L. Mena).

1 Present address: U.S. Fish and Wildlife Service, 420 S. Garfield Avenue, Suite 400, Pierre, SD 57501-5408, USA.
}

waterfowl and shorebirds, the wetlands also provide important habitat for amphibians including the spadefoot (Scaphiopus bombifrons), Woodhouse's (Anaxyrus woodhousii), and Great Plains toads (Bufo cognatus), and Blanchard's cricket (Acris crepitans blanchardi), western chorus (Pseudacris triseriata), and plains leopard frogs (Lithobates blairi; USFWS, 2007).

Historic prairie grasslands and wetland systems of the RWB have given way to an agricultural landscape of corn and soybeans (USDOI, 1994). The result has been extensive environmental modification including the draining and dewatering of an estimated $85 \%$ of the wetlands (McMurtrey et al., 1972), degradation of many remaining wetlands, and consequent loss of ecological services (Robichaux and Harrington, 2009). Contamination in extant RWB wetlands is of concern because many serve as catchment basins for agricultural runoff transporting nutrients and toxins from some of the thousands of pounds of fertilizers and pesticides applied annually to Nebraska crops (NASS, 2005, 2006).

Contaminated prairie wetlands can affect wildlife directly by way of pesticide toxicity to non-target organisms or indirectly through reduced habitat quality from nutrient enrichment (Goldsborough and Crumpton, 1998). Despite their ecological importance, few studies have been conducted to measure contaminants or evaluate health of RWB wildlife. Surveys in the early 1980's and 1990's found higher levels of arsenic, cadmium, lead, mercury, and selenium in wetlands than nearby riverine environments and wetland 


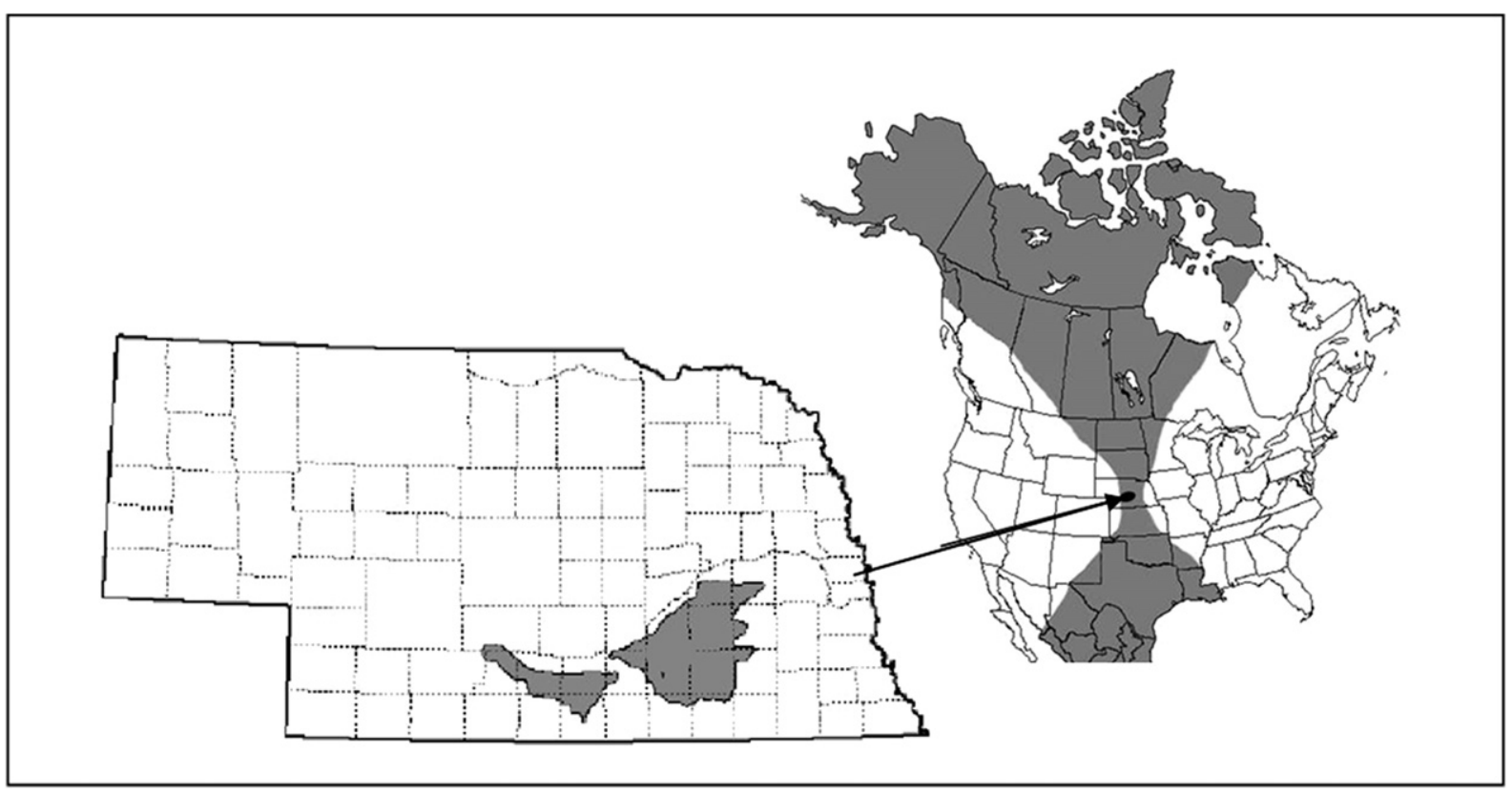

Fig. 1. Location of the Rainwater Basin in Nebraska, USA a spring migration corridor used by millions of ducks, geese, and other migratory birds annually.

concentrations of some heavy metals exceeded U.S. Environmental Protection Agency (EPA) water quality criteria (Gordon et al., 1997; Martin and Hartman, 1984). More recently, Foster (2010) monitored water quality of surface and groundwater in RWB wetlands and documented levels of concern for atrazine $(<0.05-10.3 \mathrm{ppb})$ and nitrates $(<0.1-18.4 \mathrm{mg} / \mathrm{L})$.

The present study was undertaken to assess relative differences in gonadal morphology in froglets collected from WPA wetlands in agricultural areas. A body of research has associated morphological abnormalities in amphibians with agricultural activity and agrochemicals (Bridges, 2000; Hayes et al., 2006, 2010a; Lenkowski et al., 2010; Mann et al., 2009; McCoy et al., 2008; Spolyarich et al., 2011). Amphibians are good sentinels of contaminant exposure and effects (Bernanke and Köhler, 2008). Unlike fish, amphibians can occupy ephemeral or very small water bodies, common in agricultural areas. Exposure can occur both in the aquatic and terrestrial environments, and the period of metamorphosis is a particularly vulnerable life stage (Hall and Henry, 1992). In addition, for many amphibians sexual differentiation and development, a time of high sensitivity to the adverse effects of chemicals, occurs during or proximal to the aquatic period (Hogan et al., 2010). Species of the $L$. pipiens complex are reportedly gonochoristic (Gallien, 1974) - sex is determined by sex chromosomes (female homogameity; Richards and Nace, 1978) and equal numbers of distinct male and female gonadal phenotypes are expected without an intersex developmental phase. Therefore, application of commonly used phenotypic biomarkers of endocrine disruption (sex ratio, testicular oocytes or intersex) should be useful in evaluating exposure of wild leopard frogs to those agricultural pesticides considered endocrine active chemicals.

\section{Methods}

Leopard frogs were collected from RWBWPA sites categorized as either buffered or non-buffered from row-crop agricultural runoff. As indicated by Belden et al. (2012) an unimpacted reference wetland could not be found within the RWB. Therefore, a refuge wetland located outside of the RWB without row-crop agriculture in its watershed was chosen. We evaluated three indicators associated with exposure to agricultural chemicals previously reported in the literature, sex ratio, gonad histomorphology, and thymic plaques, and compared their prevalence to land use and pesticides in water. Additionally, we evaluated the presence and severity of kidney parasite infection because of notable differences among sites during evaluation of the gonad-kidney complex and previously reported associations among agricultural chemical exposure, parasitism, and adverse effects in anurans (Kiesecker, 2002).

\subsection{Site description and collection}

Frogs were collected from four sites that received surface runoff from agricultural fields in south central Nebraska's RWB Management District. The sites were categorized as "buffered" (WPAs Atlanta and Moger) or "non-buffered" (WPAs Killdeer and McMurtery). Non-buffered sites were located near culverts that provided direct surface runoff whereas, buffered sites were greater than $50 \mathrm{~m}$ from culverts. The upland buffers were constructed in order to filter pollutants in runoff. The fifth site was located on Valentine National Wildlife Refuge (Refuge) in the Sandhills of north central Nebraska. The Refuge site was selected to evaluate leopard frogs in habitat that does not receive drainage from row-crop agriculture. Fifty leopard froglets Gosner stage 46 (Gosner, 1960) were targeted for collection at the five sites from 2007 to 2009. Each site was sampled once with the exception that Killdeer was sampled two times (2007 and 2009). Site collections were completed within a 24 -h period.

Froglets were captured according to standard operating procedures established for the USFWS National Abnormal Amphibian Program (USFWS, 2008). The day of capture, amphibians were held in a bucket of site water until transfer to the laboratory for processing. Froglets were euthanized with an overdose of tricane methanesulfonate or $\mathrm{CO}_{2}$ then measured for snout-to-vent length (SVL) to the nearest millimeter. Specimens were preserved in Bouin's solution and later shipped to the Columbia Environmental Research Center for examination and histopathology.

\subsection{Histology}

Froglets were dissected and gonad with fat body and generally some kidney attached were removed and placed in tissue cassettes. A section of the thorax was removed from 10 froglets for each collection set for histological viewing of thymus. Gonads and thoracic sections were rinsed multiple times in $70 \%$ ethanol to remove Bouin's. Tissues were processed through a graded series of xylenes and alcohols, and embedded in paraffin. Serial sections 7 um thin of approximately $50 \%$ of the paired gonad and three sections of thymus from each individual were stained with hemotoxylin and eosin and viewed by bright-field with a Nikon 90i microscope. Gonads were identified as ovary (Ogielska and Kotusz, 2004) or testis (Ogielska and Bartmanska, 1999) and abnormalities following Wolf et al. (2010) and Hecker et al. (2005) were recorded. The presence and severity of parasites (none, $<10$, or $\geq 10$ ) in kidney was also noted on those gonad slide preparations that also had kidney tissue. Thymus sections were evaluated for the presence or absence of plaques.

\subsection{Water chemistry}

Water samples for pesticide analysis were collected from WPAs in amber glass containers, immediately cooled on ice, and refrigerated until analysis for atrazine, glyphosate, and metolachlor. One or 2 samples were collected twice each month 
from April to August in years when froglets were collected. Metolachlor was only measured on samples collected in 2009. No measurements were made at the Refuge site. However, because it is surrounded by protected prairie, agricultural chemicals were expected to be minimal based on water analyses from similarly located areas (Schwarz and Lydick, 2010). Analysis was by enzyme-linked immunosorbent assay kits purchased from Abraxis ${ }^{\mathrm{TM}}$ (Warminster, PA, USA) according to manufacturer's protocols. Briefly, duplicate samples were placed into test tubes or microtiter plates and a competitive reaction for antibody binding sites was produced between the herbicide in the sample and the added enzyme-labeled herbicide analog. The resulting color was quantified by spectrophotometer (Ohmicron RPA-ITM Photometric Analyzer) at a $450 \mathrm{~nm}$ wavelength.

\subsection{Statistics}

Differences between buffered and non-buffered sites were tested with the Wilcoxon rank-sum test for incidence and severity of parasite infection, mean SVL, percent males with TOs, and percent females. Differences in frog SVL among and within sites were tested with the Kruskal-Wallace rank test. Sex ratios were tested for differences from an expected proportion of 0.5 females using the Binomial Test (Wilson and Hardy, 2002). To compare among sites for differences in the relative proportion of froglets with parasite infection or males with TOs, a chi-square test was conducted. Differences in pesticide concentrations among sites and between buffered and non-buffered sites were tested with the Kruskal-Wallace rank test or Wilcoxon rank-sum test, respectively. Monthly averages of pesticides in individual water samples (nominally 2 samples per month at each WPA) were used in the analyses, and included data only for the months when tadpoles could have been exposed, based on a 12-week larval period prior to and including month of collection. Froglets collected from Killdeer in 2007 were not included in this latter analysis because temporal water sample collection was limited during 2007. Where values for chemistry results were below detection limits, a value of half the detection limit was used to make statistical comparisons. The geometric mean of pesticide concentration measured during and two months prior to collection (estimated sensitive period of sexual differentiation) was used to calculate a Pearson's correlation coefficient with variables of mean SVL, percent males with TO, fraction of froglets that were female, percent froglets with kidney parasites, percent froglets with more than 10 parasites, and also for some graphical presentations.

\section{Results}

Two hundred ninety-three frogs were evaluated histologically from 2007 through 2009. Lithobates blairi was collected from all WPAs but was not found at the Refuge. As a result, the closely related L. pipiens (northern leopard frog) was collected from the Refuge. Frogs reached metamorphosis on different dates from June to August across sites. Most froglets had recently completed metamorphosis (Gosner stage 46), with the exception of 17 froglets captured from the Refuge in 2007 (Gosner stage 45) and 10 large frogs collected from Killdeer in 2009 (assumed overwintered from 2008). Frog data from the Refuge is reported but was not used in statistical comparisons because of possible behavioral and developmental differences between species. Data from the group of larger frogs collected at Killdeer in 2009 are reported separately from that of the smaller froglets and not used in statistical comparisons.

With few exceptions, mean SVLs differed among collections but were the same for all size and gonad type classifications within a collection (Table 1). Males captured from Atlanta and Killdeer (2007) were the same size; all other sites differed in length within sex. There were also size differences among sites of those froglets with testicular oocytes (Table 1). However, mean froglet length was not positively correlated with percent froglets with TO at a site ( $n=5, r=0.86, p=0.06)$. When body size was compared irrespective of sex category, all collection comparisons differed. There were no differences in mean froglet length between buffered and non-buffered groups $(p=0.80)$.

Female froglets from all sites were immature with diplotene oocytes in ovaries (Fig. 2A). Testes of males contained spermatogonia in tubules (Fig. 2B). Only eight froglets appeared undifferentiated. Froglets with TO were found at all sites; oocytes without follicular cells, many degenerating, were scattered throughout testicular tissue. The percent of froglets with TO ranged from $2 \%$ at Moger to $12 \%$ at Killdeer (2007) (Table 1; Fig. 2C). A significantly greater proportion of froglets had TO at Killdeer (2007) than Moger $(p=0.05)$; all other site pairwise comparisons were the same $(p \geq 0.08)$. No difference could be detected in the proportion of TO froglets between buffered and non-buffered sites $(p=0.80)$. Unlike any other site, $20 \%$ of female froglets collected at Killdeer (2007) were classified as having ovarian dysgenesis (Table 1; Fig. 2D). All contained areas where the ovarian cavity was enlarged, often with an irregular contour, and appeared to contain fluid. These ovaries had scattered diplotene oocytes among oogonia and often oocytes within the lumen of the cavity. The larger, presumably overwintered frogs collected at Killdeer in 2009 all had normal ovaries and testes containing vitellogenic oocytes and spermatozoa, respectively.

Overall, 169 (70\%) of the L. blairi methamorphs were female of the total $241 \mathrm{~L}$. blairi froglets not identified as undifferentiated. Sex ratios ranged from 1:0.8 to $1: 2.6$ phenotypic males to phenotypic females with no difference between buffered and non-buffered sites ( $p=0.80$; Table 1$)$. Proportionally, more females were present in collections from Refuge $(p=0.0352)$, McMurtrey $(p=0.0263)$, Moger $(p=0.0009)$, and Killdeer $(2007)(p=0.008)$. There was no difference in sex ratios at Atlanta and Killdeer (2009) but numerically more males were found at the Killdeer WPA.

An unidentified trematode parasite metacercaria was common in kidneys of froglets from most sites. Both sexes showed a similar pattern of infection although there were some differences in

Table 1

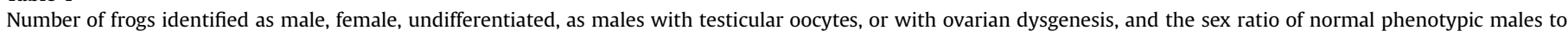

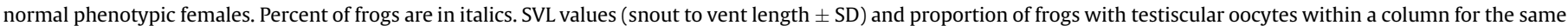
endpoint and with the same superscript are not different. An asterisk indicates significantly different from a 1:1 ratio.

\begin{tabular}{|c|c|c|c|c|c|c|c|c|c|}
\hline Site & Species & $\begin{array}{l}\text { Collection } \\
\text { month/year }\end{array}$ & Total & $\begin{array}{l}\text { No. females } \\
\text { (SVL mm) }\end{array}$ & $\begin{array}{l}\text { No. males } \\
\text { (SVL mm) }\end{array}$ & $\begin{array}{l}\text { Testicular } \\
\text { oocytes (mm) }\end{array}$ & $\begin{array}{l}\text { Ovarian dysgenesis } \\
(\mathrm{mm})\end{array}$ & $\begin{array}{l}\text { Undifferentiated } \\
(\mathrm{mm})\end{array}$ & $\begin{array}{l}\text { Sex } \\
\text { ratio M:F }\end{array}$ \\
\hline Killdeer & L. blairi & $06 / 2007$ & 50 & $\begin{array}{l}30 \\
(42 \pm 2)^{\mathrm{a}}\end{array}$ & $\begin{array}{l}14 \\
(42 \pm 2)^{a}\end{array}$ & $\begin{array}{l}6,12 \%^{a} \\
(43 \pm 3)^{a}\end{array}$ & $\begin{array}{l}10,20 \% \\
(42 \pm 2)\end{array}$ & $\begin{array}{l}0 \\
-\end{array}$ & $1: 2.1^{*}$ \\
\hline Killdeer & L. blairi & $\begin{array}{l}08 / 2009 \\
\text { Size group I }\end{array}$ & 39 & $\begin{array}{l}16 \\
(32 \pm 3)^{b}\end{array}$ & $\begin{array}{l}21 \\
(32 \pm 5)^{b}\end{array}$ & $\begin{array}{l}1,3 \%{ }^{\mathrm{ab}} \\
(39)^{\mathrm{ab}}\end{array}$ & $\begin{array}{l}0 \\
-\end{array}$ & $\begin{array}{l}1 \\
(31)\end{array}$ & $1: 0.8$ \\
\hline Killdeer & L. blairi & $\begin{array}{l}\text { 06\&08/2009 } \\
\text { Size group II }\end{array}$ & 10 & $\begin{array}{l}6 \\
(50 \pm 1)^{c}\end{array}$ & $\begin{array}{l}4 \\
(55 \pm 3)^{c}\end{array}$ & $\begin{array}{l}0 \\
-\end{array}$ & $\begin{array}{l}0 \\
-\end{array}$ & $\begin{array}{l}0 \\
-\end{array}$ & $1: 1.5$ \\
\hline McMurtrey & L. blairi & $07 / 2008$ & 50 & $\begin{array}{l}29 \\
(39 \pm 3)^{d}\end{array}$ & $\begin{array}{l}13 \\
(38 \pm 2)^{d}\end{array}$ & $\begin{array}{l}3,7 \%^{\mathrm{ab}} \\
(38 \pm 1)^{\mathrm{b}}\end{array}$ & $\begin{array}{l}0 \\
-\end{array}$ & $\begin{array}{l}5 \\
(39 \pm 1)\end{array}$ & $1: 2.2^{*}$ \\
\hline Moger & L. blairi & $08 / 2009$ & 50 & $\begin{array}{l}36 \\
(29 \pm 2)^{\mathrm{e}}\end{array}$ & $\begin{array}{l}13 \\
(29 \pm 2)^{\mathrm{e}}\end{array}$ & $\begin{array}{l}1,2 \%^{\mathrm{b}} \\
(32)^{\mathrm{b}}\end{array}$ & $\begin{array}{l}0 \\
-\end{array}$ & $\begin{array}{l}0 \\
-\end{array}$ & $1: 2.8^{*}$ \\
\hline Atlanta & L. blairi & $07 / 2008$ & 50 & $\begin{array}{l}24 \\
(41 \pm 2)^{f}\end{array}$ & $\begin{array}{l}19 \\
(40 \pm 4)^{\mathrm{a}}\end{array}$ & $\begin{array}{l}5,10 \%{ }^{a b} \\
(43 \pm 2)^{a}\end{array}$ & $\begin{array}{l}0 \\
-\end{array}$ & $\begin{array}{l}2 \\
(41)\end{array}$ & $1: 1.3$ \\
\hline Valentine & L. pipiens & $07 / 2007$ & $44^{1}$ & $\begin{array}{l}28 \\
(38 \pm 5)\end{array}$ & $\begin{array}{l}13 \\
(40 \pm 4)\end{array}$ & $\begin{array}{l}3,7 \% \\
(44 \pm 5)\end{array}$ & $\begin{array}{l}0 \\
-\end{array}$ & $\begin{array}{l}0 \\
-\end{array}$ & $1: 2.2^{*}$ \\
\hline
\end{tabular}



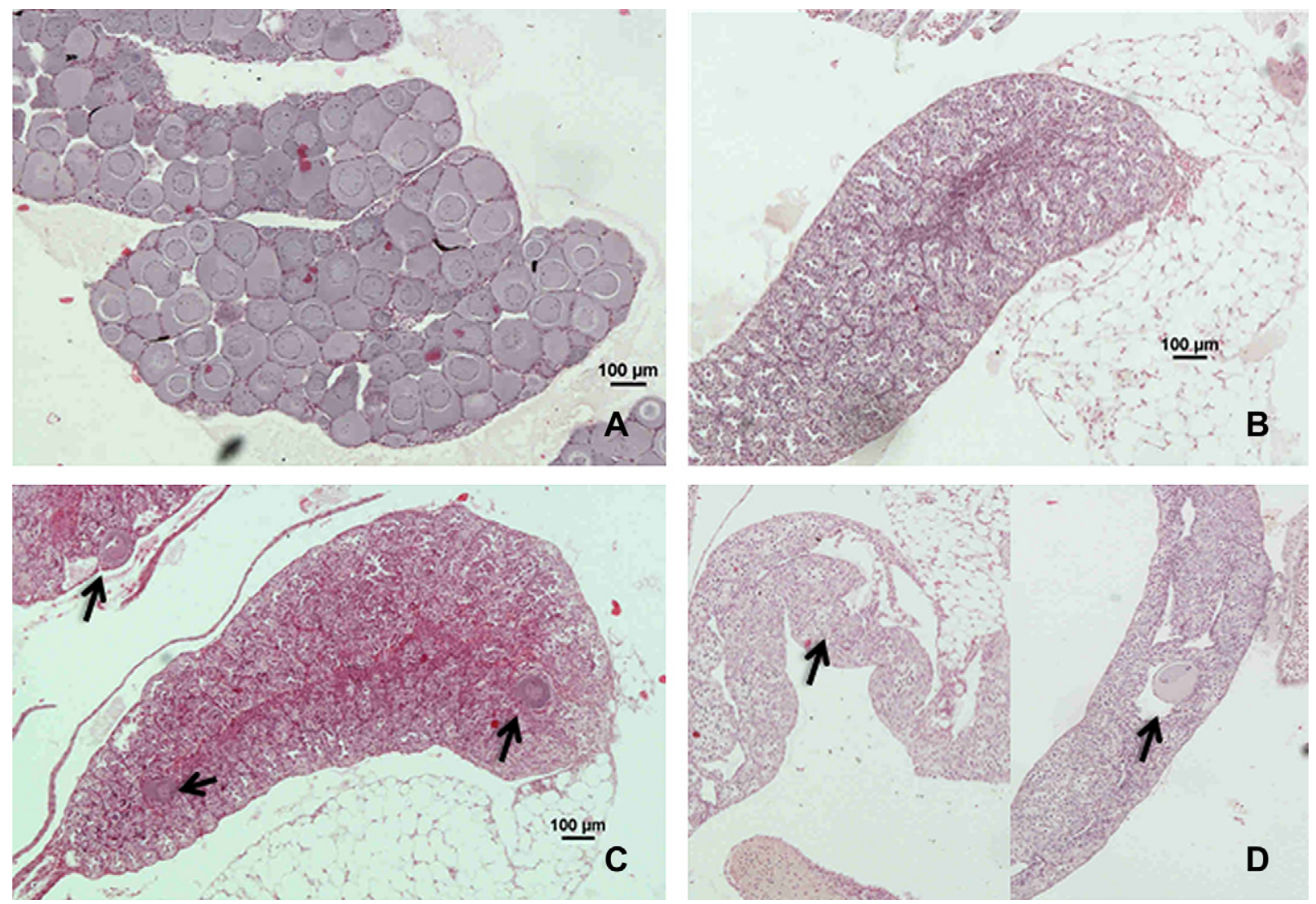

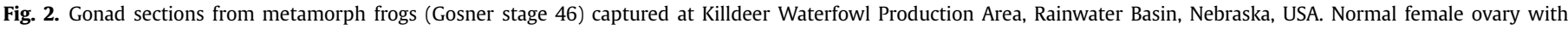

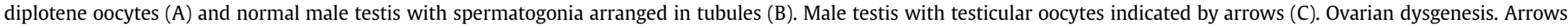
point to enlarged ovarian cavity and diplotene oocyte within cavity (D).

parasite loads among sites (Table 2). Only one froglet from Atlanta, a male with TO, was without parasites (Table 2). Killdeer (2007) had the most froglets without parasites $(p \leq 0.0004$, for all site pairwise comparisons; Table 2). The proportion of froglets with parasites for the remaining sites were intermediate with Moger and Killdeer (2009) having equivalent proportions $(p=0.4173)$. The proportion of froglets with more than 10 parasites was highest for Atlanta ( $p \leq 0.0001$, all site pairwise comparisons) and lowest for Killdeer (2007) froglets $(p \leq 0.0012)$ when compared to all other sites. There was no difference in incidence or severity of parasites between buffered and non-buffered sites ( $p \geq 0.20$ ). There was no discernible pattern of parasite infection in froglets with testicular oocytes (Table 2). Thymic plaques, an indicator of effects on the immune system, were not observed in any froglets.

Chemical concentrations varied among sites and seasonally (Table 3). Glyphosate was highest among sites in June and July. Average monthly concentrations ranged from undetectable at
Atlanta and Killdeer WPAs to $10.7 \mu \mathrm{g} / \mathrm{L}$ at McMurtrey WPA (Table 3). Glyphosate was not detected any month at Atlanta. Glyphosate concentrations were highest overall at McMurtrey, followed by Killdeer (2009) $(p<0.0001)$ and buffered sites were lower than non-buffered ( $p=0.003$ ). Metolachlor concentrations peaked in May at Moger and June at Killdeer (2009); the only two sites where metolachlor measurements were made coincident with frog capture (Table 3). Overall, metolachlor was higher at Killdeer (2009) $(p=0.0171)$ and buffered sites were significantly lower than non-buffered sites $(p=0.0437)$. Atrazine peaked at Atlanta and Killdeer (2009) in June and July and at McMurtrey and Moger in May and June (Table 3). Atrazine concentrations were highest at Killdeer (2009) and lowest at Moger $(p=0.0088)$. Buffered sites were significantly lower in atrazine than non-buffered sites $(p=0.039)$. There were no correlations between concentrations of chemicals and percentages of males, females, or froglets with testicular oocytes.

Table 2

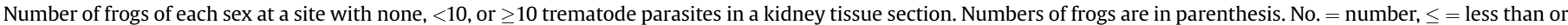
equal to, $\geq=$ greater than or equal to, $\mathrm{NB}=$ not buffered, $\mathrm{B}=$ buffered, $\mathrm{R}=$ refuge.

\begin{tabular}{|c|c|c|c|c|c|c|c|c|c|c|}
\hline \multirow[t]{2}{*}{ Site } & \multicolumn{3}{|c|}{ Percent male (No.) } & \multicolumn{3}{|c|}{ Percent female (No.) } & \multicolumn{3}{|c|}{$\begin{array}{l}\text { Percent males with } \\
\text { testicular oocytes (No.) }\end{array}$} & \multirow[t]{2}{*}{ Total frogs } \\
\hline & None & $<10$ & $\geq 10$ & None & $<10$ & $\geq 10$ & None & $<10$ & $\geq 10$ & \\
\hline NB-Killdeer ('07) & $80(8)$ & $20(2)$ & 0 & $100(4)$ & 0 & 0 & $100(6)$ & 0 & 0 & 20 \\
\hline NB-Killdeer ('09) & $24(5)$ & $67(14)$ & $9(2)$ & $21(4)$ & $54(7)$ & $15(2)$ & 0 & $100(1)$ & 0 & 35 \\
\hline NB-McMurtrey & $46(6)$ & $38(5)$ & $16(2)$ & $38(8)$ & $57(12)$ & $5(1)$ & $33(1)$ & $33(1)$ & $33(1)$ & 37 \\
\hline B-Moger & $8(1)$ & $67(8)$ & $17(2)$ & $29(7)$ & $71(17)$ & 0 & 0 & $100(1)$ & 0 & 36 \\
\hline B-Atlanta & 0 & $53(9)$ & $47(8)$ & 0 & $46(1)$ & $54(13)$ & $25(1)$ & 0 & $75(3)$ & 45 \\
\hline R-Valentine & $38(5)$ & $62(8)$ & 0 & $56(10)$ & $44(8)$ & 0 & $33(1)$ & $33(1)$ & $33(1)$ & 34 \\
\hline
\end{tabular}


Table 3

Pesticide concentrations in water from wetland WPA sites in Nebraska. Months when frogs were collected are in bold. All frogs were at Gosner stage 46 except those collected from Killdeer, June 2009. Values represent 1 sample or the average of 2 samples. 'No data' indicates the sample was not analyzed for that pesticide.

\begin{tabular}{llllll}
\hline Site & Year & Month & \multicolumn{2}{l}{ Pesticide $(\mathrm{ug} / \mathrm{L})$} \\
\cline { 5 - 6 } & & & Atrazine & Glyphosate & Metolachlor \\
\hline Killdeer & 2007 & June & $5.59^{\mathrm{a}}$ & No data & No data \\
Killdeer & 2009 & April & 0.41 & $<0.15$ & 0.12 \\
Killdeer & 2009 & May & 0.98 & 0.13 & 0.25 \\
Killdeer & 2009 & June & 49.10 & 1.15 & 0.52 \\
Killdeer & 2009 & July & 33.80 & 0.24 & 0.24 \\
Killdeer & 2009 & August & 22.20 & 0.28 & 0.22 \\
McMurtrey & 2008 & April & No data & 0.05 & No data \\
McMurtrey & 2008 & May & 47.85 & No data & No data \\
McMurtrey & 2008 & June & 13.90 & 10.70 & No data \\
McMurtrey & 2008 & July & 1.30 & 5.15 & No data \\
McMurtrey & 2008 & August & 0.03 & No data & No data \\
Moger & 2009 & April & 0.22 & 0.09 & $<0.07$ \\
Moger & 2009 & May & 0.99 & 0.07 & 0.29 \\
Moger & 2009 & June & 0.80 & 0.11 & $<0.07$ \\
Moger & 2009 & July & 0.46 & 0.10 & 0.10 \\
Moger & 2009 & August & 0.09 & $<0.15$ & $<0.07$ \\
Atlanta & 2008 & April & 0.26 & $<0.1$ & No data \\
Atlanta & 2008 & May & 0.61 & $<0.1$ & No data \\
Atlanta & 2008 & June & 3.23 & $<0.1$ & No data \\
Atlanta & 2008 & July & 2.50 & $<0.1$ & No data \\
\hline anyyyy This is & & & &
\end{tabular}

a This is a one occasion sample that was run in duplicate and indicates an atrazine concentration $>5 \mathrm{ppb}$.

b Overwintered frogs collected on this date.

\section{Discussion}

\subsection{Land-use effects}

North American anurans collected in close proximity to active agriculture are reported to have gonadal anomalies (McCoy et al., 2008) and experience adverse effects from parasitism (Kiesecker, 2002; Marcogliese et al., 2009). In the present study, TOs were the most commonly observed anomaly and it was observed in some leopard frogs from refuge and WPA wetlands regardless of whether or not they were buffered against contamination from field run-off. Ovarian dysgenesis was also observed at one unbuffered WPA site that also had the highest incidence of testicular oocytes. Similarly, a percentage of $L$. pipiens males collected by Hayes et al. (2003) in Nebraska and Iowa, Murphy et al. (2006) in Michigan, and McDaniel et al. (2008) in Ontario, also had TOs, regardless of whether or not they were from agricultural areas. McDaniel et al. (2008) reported higher rates of TO in agricultural areas, a trend not clearly observed in the present study. Inconsistent rates of TO, as observed between years at Killdeer WPA, were also reported by Murphy et al. (2006) for L. pipiens and L. clamitans.

A percentage of froglets from all sites were infected with a parasite. The percent of froglets infected in this study was not associated with SVL, wetland buffering, or pesticide concentration. The greatest percentage of froglets with more than 10 parasites came from a buffered site and an unbuffered site had the fewest with parasites. Froglets at the unbuffered Killdeer site in 2007 had fewer parasites than the froglets at this same site two years later. Incomplete water quality and pesticide information for 2007 precludes explanation of the temporal differences in parasite loads at the same site. A greater trematode exposure at agricultural than non-agricultural sites has previously been reported for $L$. sylvatica (Kiesecker, 2002) and L. catesbiana (Marcogliese et al., 2009). Johnson et al. (2007) attributed a higher rate of parasitized amphibians to eutrophication of wetland areas as a result of nutrient enrichment from field run-off. However, the WPA sites sampled in the present study were all similarly nutrient-rich (supplemental data). Geographic and temporal differences in parasite loads are likely due to a suite of site-specific conditions including the direct and indirect effects of the pesticide mixtures on the parasite or hosts (Christin et al., 2004; Koprivnikar et al., 2007; Rohr et al., 2008).

\subsection{Pesticide exposure}

Agriculture in the RWB is dependent on use of pesticides and fertilizers. Crops produced include grains (corn, wheat, milo, and sorghum), soybeans, and alfalfa (USDOI, 1994) with corn predominating. Glyphosate and atrazine are two chemicals commonly used on corn and soybeans in the Rainwater Basin (NASS, 2005, 2006). Technical grade glyphosate is practically non-toxic to freshwater fish and invertebrates (USEPA, 1993) however, the surfactant composition of certain glyphosate formulations can increase toxicity and time to metamorphosis in non-target species, especially amphibians (Howe et al., 2004; Mann and Bidwell, 1999; Relyea, 2005 a-d; Williams and Semlitsch, 2010). There are no EPA or Nebraska water quality criteria for glyphosate, but WPA waters were below an interim Canadian guideline of $65 \mu \mathrm{g} / \mathrm{L}$ (CCME, 1999). No reproductive anomalies or incidence of parasitism at WPAs were associated with glyphosate. Glyphosate and atrazine are not applied to WPAs in the RWB, however, they can be transported to them in runoff, groundwater seepage, and aerial over-spray. This was reflected by high atrazine at WPAs in May through July coincident with summer rains and lowest measurements in April before the rainy season and late August post application. Atrazine at the two unbuffered sites exceeded Nebraska's chronic aquatic life criterion of $12 \mu \mathrm{g} / \mathrm{L}$ (NDEQ, 2009) on multiple occasions and during $L$ blairi's aquatic developmental period. Gonadal anomalies were highest at one of these WPAs. At this same site (Killdeer, 2007), the number of parasitized froglets was lowest. Perhaps explained by direct toxicity of atrazine on the parasite or because atrazine effected a change in the trophic conditions that in turn reduced snail hosts (Koprivnikar et al., 2006). After atrazine and glyphosate, metolachlor was the third most applied herbicide on Nebraska corn (NASS, 2006). Although detected at WPAs, the highest concentration of metolachlor measured was well below Nebraska's $100 \mu \mathrm{g} / \mathrm{L}$ chronic aquatic life standard (NDEQ 2009). Landscape modifications that buffered the wetlands from runoff may have been effective. Pesticide concentrations overall were lower at buffered compared to non-buffered sites. However, differences may also reflect annual precipitation, crop rotations, or site-specific application rates.

\subsection{Atrazine association with sex ratio and TO}

Nebraska applied 7.7 million pounds of atrazine in 2006, twice that of glyphosate or metolachlor (NASS, 2011). Atrazine controls broadleaf weeds by inhibiting photosynthesis and can be toxic to non-target organisms by several mechanisms including endocrine disruption. Skewed sex ratios and presentation with TO are two endocrine-mediated effects often associated with amphibian exposure to atrazine. In the present study, no correlation between atrazine concentrations and incidence of TO or percentages of females were found despite measured concentrations of between 0.09 and $22.20 \mu \mathrm{g} / \mathrm{L}$ atrazine at the time froglets were collected. Neither have the endocrine-mediated effects of atrazine been consistently observed for the most studied species, Xenopus, or among frog species generally (Carr et al., 2003; Coady et al., 2004, 2005; Du Preez et al., 2009; Jooste et al., 2005; Kloas et al., 2009; LaFiandra et al., 2008; Oka et al., 2008; Storrs-Ménedz and Semlitsch, 2009). Similarly, field studies have not consistently associated high environmental levels of atrazine with biased sex 
ratios or testicular oocytes (Murphy et al., 2006; Spolyarich et al., 2010). Nevertheless, there appears to be more conformity of results among atrazine studies with frogs of the L. pipiens complex (includes L. sphenocephala and L. blairi). Generally, there are more females than males and males exhibit TO when exposed to atrazine; but female-biased sex ratios and TO don't always coincide. Langlois et al. (2010) showed that exposure of L. pipiens to $0.1 \mu \mathrm{g} / \mathrm{L}$ atrazine did not affect sex ratio but at $1.8 \mu \mathrm{g}$ atrazine/L from Gosner stage 27 to metamorphosis significantly more females than males resulted; no males showed testicular oocytes. Orton et al. (2006) found $10 \mu \mathrm{g} / \mathrm{L}$ atrazine did not affect the relative proportion of L. pipiens females, but when combined with $10 \mathrm{mg} / \mathrm{L}$ nitrate females were more prevalent; TO were found in controls and treatments. Lithobates sphenocephala (southern leopard frog) female metamorphs were proportionally more prevalent than males, compared to the sex ratio for controls, when exposed to $3 \mu \mathrm{g} / \mathrm{L}$ atrazine through the critical period of sexual differentiation ( 15 females and 9 males (normal plus TO) for all weeks combined from Storrs and Semlitsch, 2009). The proportion of froglets with TO relative to normal males was greater than in controls (Storrs and Semlitsch, 2009). In the same experiment, at $30 \mu \mathrm{g} / \mathrm{L}$ there was a decrease in the proportion of females and a further increase in the proportion of froglets with testicular oocytes (Storrs and Semlitsch, 2009). Later, as juveniles, frogs that had been exposed to either 17$\beta$ estradiol or $10 \mu \mathrm{g} / \mathrm{L}$ atrazine through the larval period had a greater percentage of females than males and also males with TO whereas, control frogs had equivalent numbers of males and females and no males with testicular oocytes (Storrs and Semlitsch, 2009). Species of the $L$ pipiens complex are not generally believed to pass through a juvenile intersex period, yet both $L$. pipiens and L. sphenocephala unexposed to chemicals during development have been shown to produce TOs that regress after metamorphosis. Moreover, exposure to a feminizing chemical during the larval period may lead to reduced numbers of phenotypically normal males because genetic males appear as phenotypic females or persist in expressing TO when examined beyond metamorphosis as juveniles. The recent demonstration that $2.5 \mu \mathrm{g} / \mathrm{L}$ of atrazine sexreversed known genetic Xenopus males to phenotypic functional females (Hayes et al., 2010b) further substantiates an as yet unidentified feminizing or demasculinizing mechanism (Hayes et al., 2011) for the herbicide that could account for the greater numbers of phenotypic females over males.

\subsection{Sexual and somatic development and timing of exposure}

Whether or not atrazine feminizes or demasculinizes male frogs has been vigorously examined and as a result, a greater understanding of how endocrine disruptors may affect amphibians with complex life cycles is emerging. Ogielska and Kotusz (2004) proposed that among frog species the somatic and gonadal development rates are not synchronized and that the stage of ovarian development reached at tail absorption will vary among species that complete metamorphosis aquatically. Furthermore, they ascribe one of three general differential rate types to a given species. Ogielska and Kotusz (2004) identify L. pipiens as an accelerated type, meaning that the froglet metamorphs will have passed through the period of sexual differentiation early in development and by Gosner Stage 46 the ovary will be well-developed. The research of Storrs-Méndez and Semlitsch (2009) supports this concept for both $L$. pipiens and $L$. sphenocephala (Storrs and Semlitsch, 2008). In contrast, Xenopus and Bufo have basic and retarded rates, respectively (Ogielska and Kotusz, 2004; Storrs and Semlitsch, 2008). Storrs-Mendéz and Semlitsch (2009) also found that different species of frogs exposed similarly to estrogens or atrazine will respond differently according to their rate type because of developmental timing of the critical period of sexual differentiation. Exposure to endocrine disrupting chemicals during the critical period can alter the outcome of sexual differentiation. The critical period for $L$. pipiens begins at 3 weeks post-hatch (Frigden, 2009), generally several weeks prior to metamorphosis. Exposure to estrogens during this period causes a female-biased shift in the sex ratio for L. pipiens (Hogan et al., 2008; Mackenzie et al., 2003). Sexual differentiation in L. sphenocephala is also many weeks prior to metamorphosis and exposure to estrogens during this time feminizes the frogs (Storrs-Mendéz and Semlitsch, 2009).

Whereas gonadal development rate seems to be fixed for a species, somatic development varies within species (StorrsMendéz and Semlitsch, 2009). Furthermore, time to and size at metamorphosis can vary among populations of the same species depending on environmental conditions. This likely explains why RWB froglets, although collected at the same developmental stage, Gosner 46, differed among sites in size at metamorphosis despite having similarly developed gonads. As a result, among WPA wetlands the time course of exposure of the RWB L. blairi tadpoles to agricultural chemicals would vary and could in part explain the differences in sex ratios and percent froglets with TOs among collections.

\subsection{Are Rainwater Basin frogs exposed to endocrine active chemicals at concentrations that elicit biomarker responses?}

An objective of this study was to assess whether froglets collected from wetlands in agricultural areas displayed gonad phenotypes characteristic of exposure to endocrine active chemicals. However, differences among anurans in the timing and specific characteristics of sexual differentiation and development makes interpreting biomarkers of exposure to endocrine disruptors challenging (Storrs-Mendéz and Semlitsch, 2009). Although sexual differentiation and developmental biology of $L$. pipiens and L. sphenocephala has been described, no information exists for L. blairi. However, based on phylogenetic proximity it may be assumed that $L$. blairi would have a similar developmental phenotype (accelerated), early sexual differentiation, a transient TO phase prior to metamorphosis, and an approximate $1: 1$ adult sex ratio (Frost et al., 2006; Hillis, 1988; Hillis and Wilcox, 2005). These assumptions underlie the interpretation of the RWB study results.

Seemingly, the results of the present study indicate no environmental effect of the agricultural chemicals on sexual development of $L$. blairi. There was no clear association between land use or concentration of chemicals measured and percent of females despite female-biased sex ratios in the majority of collections or overall. Testicular oocytes were seen in a percentage of male froglets from every collection during the three years of the study but, similar to the sex ratio metric, there was no clear effect of land use or chemicals measured in the wetlands. Nevertheless, considering the results of Storrs-Méndez and Semlitsch (2009) and others, another interpretation is plausible. If in fact $L$. blairi responds to atrazine similar to the leopard frogs in the Storrs-Méndez and Semlitsch (2009) experiments, then a population of RWB metamorphs exposed to $\geq 3 \mu \mathrm{g} / \mathrm{L}$ atrazine during larval development would be predicted to have a preponderance of females or froglets with testicular oocytes and few normal males. In contrast, an unaffected population should have approximately $50 \%$ female metamorphs and the remaining metamorphs would be a mixture of normal males and males with transient testicular oocytes. The juveniles and adults should maintain the female-biased sex ratio and TO in contrast to the unaffected population. Accordingly, froglets from the WPA sites, Killdeer (2007), McMurtrey, and Atlanta, with high percentages of females and froglets with TO, low 
percentage of normal phenotypic males, and atrazine concentrations during the developmental period $>3 \mu \mathrm{g} / \mathrm{L}$, are likely candidates for an atrazine-related effect. The lack of an effect at Killdeer (2009) despite high concentrations of atrazine in spring of 2009, may be due to a short exposure period suggested by the small size of the metamorphs.

Upland buffers were effective at reducing the concentration of atrazine, metolachlor, and glyphosate in wetlands. Nevertheless, RWB L. blairi in buffered and non-buffered WPAs are exposed to atrazine during gonad development and germ cell proliferation at concentrations previously found to elicit gonad abnormalities in closely related species. Although the same suite of effects were observed in froglets in the present study (TOs, gonadal dysgenesis, skewed sex ratios) no statistical relationship to atrazine concentration existed. Uncertainties about the timing and duration of exposure and most importantly an incomplete understanding of the normal gonadal morphology during sex differentiation and development of $L$. blairi prevented a clear understanding of the relationship between agricultural chemical use in the RWB and the appearance of TOs and skewed sex ratios. Nevertheless, the evidence supports a plausible exposure to atrazine during sexual development, of sufficient magnitude and duration at some of the WPA sites, to explain the observed reproductive effects. The results remain inconclusive however, without data from the juvenile or adult life stage that indicate a reduction in the percentage of normal phenotypic males and persistence of testicular oocytes. The results of this study highlight the importance of understanding the normal reproductive biology of the species of interest and the influence that spatial and temporal variability can have on amphibian gonadal phenotype.

\section{Disclaimer}

Any use of trade, product, or firm names is for descriptive purposes only and does not imply endorsement by the U.S. Government.

\section{Acknowledgments}

The authors wish to thank Mandy Annis and Vanessa Veléz for specimen preparation for histology. Julia Towns-Campbell provided invaluable library support. Dr. Jeffrey Wolf, Experimental Pathology Laboratory, reviewed a subset of slides from Killdeer 2007. Dr. Bethany Willams, Dr. Sara Storrs-Mendéz provided valuable manuscript reviews. This project was funded through the U.S. Fish and Wildlife Off-Refuge grants program.

\section{Appendix A. Supplementary data}

Supplementary data associated with this article can be found, in the online version, at http://dx.doi.org/10.1016/j.envpol.2012.07.042.

\section{References}

Belden, J.B., Hanson, B.R., McMurry, S.T., Smith, L.M., Haukos, D.A., 2012. Assessment of the effects of farming and conservation programs on pesticide deposition in high plains wetlands. Environmental Science and Technology 46, 3424-3432.

Benning, D.S., 1987. Coordinated Mid-continent White-fronted Goose Survey. U. S. Fish and Wildlife Service, Annual Report, Fish and Wildlife Service, Washington.

Bernanke, J., Köhler, H.-R., 2008. The impact of environmental chemicals on wildlife vertebrates. Review of Environmental Contamination and Toxicology 198, 1-47.

Bortner, J.B., Johnson, F.A., Smith, G.W., Trost, R.E., 1991. Status of Waterfowl and Fall Flight Forecast. U.S. Fish and Wildlife Service, Washington.

Bridges, C.M., 2000. Long-term effects of pesticide exposure at various life stages of the southern leopard frog (Rana sphenocephala). Archives of Environmental Contamination and Toxicology 39, 91-96.

CCME (Canadian Council of Ministries of the Environment), 1999. Canadian water quality guidelines for the protection of aquatic life: glyphosate. In: Canadian
Council of Ministers of the Environment, Canadian Environmental Quality Guidelines, 1999. Winnipeg, Manitoba.

Carr, J.A., Gentles, A., Smith, E.E., Goleman, W.L., Urquidi, L.J., Thuett, K., Kendall, R.J., Giesy, J.P., Gross, T.S., Solomon, K.R., Van Der Kraak, G., 2003. Response of larval Xenopus laevis to atrazine: assessment of growth, metamorphosis, and gonadal and laryngeal morphology. Environmental Toxicology and Chemistry 22, 396405.

Christin, M.-S., Gendron, A.D., Brousseau, P., Menard, L., Marcogliese, D.J., Cyr, D., Ruby, S., Fournier, M., 2004. Effects of agricultural pesticides on the immune system of Xenopus laevis and Rana pipiens. Aquatic Toxicology 67, 33-43.

Coady, K.K., Murphy, M.B., Villeneuve, D.L., Hecker, M., Jones, P.D., Carr, J.A., Solomon, K.R., Smith, E.E., Van Der Kraak, G., Kendall, R.J., Giesy, J.P., 2004. Effects of atrazine on metamorphosis, growth, and gonadal development in the green frog (Rana clamitans). Journal of Toxicology and Environmental Health, Part A 67, 941-957.

Coady, K.K., Murphy, M.B., Villeneuve, D.L., Hecker, M., Jones, P.D., Carr, J.A., Solomon, K.R., Smith, E.E., Van Der Kraak, G., Kendall, R.J., Giesy, J.P., 2005. Effects of atrazine on metamorphosis, growth, laryngeal and gonadal development, aromatase activity, and sex steroid concentrations in Xenopus laevis. Ecotoxicology and Environmental Safety 62, 160-173.

Du Preez, L.H., Kunene, N., Everson, G.J., Carr, J.A., Giesy, J.P., Gross, T.S., Hosmer, A.J., 2009. Reproduction, larval growth, and reproductive development in African clawed (Xenopus laevis) exposed to atrazine. Chemosphere 71, 546-552.

Foster, S.E., 2010. Temporal and Spatial Variations of Ions, Isotopes and Agricultural Contaminants in Surface Waters and Groundwater of Nebraska's Rainwater Basin Wetland Region. Dissertation, University of Nebraska, Lincoln, NE.

Frigden, C.M., 2009. Laboratory controlled normal and atrazine exposed development of northern leopard frog Rana pipiens tadpoles. Thesis, Trent University, Peterborough, Ontario, Canada.

Frost, D.R., Grant, T., Faivovich, J., Bain, R.H., Haas, A., Haddad, C.F.B., O de Sá, R., Channing, R., Wilknson, M., Donnellan, S.C., Raxworthy, C.J., Campbell, J.A., Blotto, B.L., Moler, P., Drewes, R.C., Nussbaum, R.A., Lynch, J.D., Green, D.M., Wheeler, W.C., 2006. The amphibian tree of life. Bulletin of the American Museum of Natural History 297, 1-291.

Gallien, L., 1974. Intersexuality. In: Lofts, B. (Ed.), Physiology of the Amphibia, vol. 2. Academic Press, New York, pp. 523-549.

Goldsborough, L.G., Crumpton, W.G., 1998. Distribution and environmental fate of pesticides in prairie wetlands. Great Plains Research 8, 73-95.

Gordon, C.C., Flake, L.D., Higgins, K.F., 1997. Trace metals in water and sediments of wetlands in the Rainwater Basin area of Nebraska. Proceedings of the South Dakota Academy of Sciences 72, 253-261.

Gosner, K.L., 1960. A simplified table for staging anuran embryos and larvae with notes on identification. Herpatologica 16, 183-190.

Hall, R.J., Henry, P.F.P., 1992. Assessing effects of pesticides on amphibians and reptiles: status and needs. Herpetological Journal 2, 65-71.

Hayes, T., Haston, K., Tsui, M., Hoang, A., Haeffele, C., Vonk, A., 2003. Atrazineinduced hermaphroditism at $0.1 \mathrm{ppb}$ in American leopard frogs (Rana pipiens): laboratory and field evidence. Environmental Health Perspectives 111, 568-575.

Hayes, T.B., Anderson, L.L., Beasley, V.R., de Solla, S.R., Iguchie, T., Ingraham, H., Kestemont, P., Kniewald, J., Kniewald, Z., Langlois, V.S., Luque, E.H., McCoy, K.A., Muñoz-de-Toro, M., Oka, T., Oliveira, C.A., Orton, F., Ruby, S., Suzawa, M., TaveraMendoza, L.E., Trudeau, V.L., Victor-Costa, A.B., Willingham, E., 2011. Demasculinization and feminization of male gonads by atrazine: consistent effects across vertebrate classes. Journal of Steroid Biochemistry and Molecular Biology 127 (1-2), 64-73.

Hayes, T.B., Falso, P., Gallipeau, S., Stice, M., 2010a. The cause of global amphibian declines: a developmental endocrinologist's perspective. Journal of Experimental Biology 213, 921-933.

Hayes, T.B., Khoury, V., Narayan, A., Nazir, M., Park, A., Brown, T., Adame, L., Chan, E., Buchholz, D., Stueve, T., Gallipeau, S., 2010b. Atrazine induces complete feminization and chemical castration in male African clawed frogs (Xenopus laevis). Proceedings of the National Academy of Sciences of the United States of America 107, 4612-4617.

Hayes, T.B., Stuart, A.A., Mendoza, M., Collins, A., Noriega, N., Vonk, A., Johnston, G., Liu, R., Kpodzo, D., 2006. Characterization of atrazine-induced gonadal malformations in African clawed frogs (Xenopus laevis) and comparisons with effects of an androgen antagonist (cyproterone acetate) and exogenous estrogen (17-beta estradiol): support for the demasculinization. Environmental Health Perspectives 114, 134-141.

Hecker, M., Kim, W.J., Park, J.-W., Murphy, M.B., Villeneuve, D., Coady, K.K., Jones, P.D., Soloman, K.R., Van Der Kraak, G., Carr, J.A., Smith, E.E., du Preez, L., Kendall, R.J., Giesy, J.P., 2005. Plasma concentrations of estradiol and testosterone, gonadal aromatase activity and ultrastructure of the testis in Xenopus laevis exposed to estradiol or atrazine. Aquatic Toxicology 72, 383-396.

Hillis, D.M., 1988. Systematics of the Rana pipiens complex: puzzle and paradigm. Annual Review of Ecology and Systematics 19, 39-63.

Hillis, D.M., Wilcox, T.P., 2005. Phylogeny of the new world true frogs (Rana). Molecular Phylogenetics and Evolution 34, 299-314.

Hogan, N.S., Duarte, P., Wade, M.G., Lean, D.R.S., Trudeau, V.L., 2008. Estrogenic exposure affects metamorphosis and alters sex ratios in the northern leopard frog (Rana pipiens): identifying critically vulnerable periods of development. General and Comparative Endocrinology 156, 515-523.

Hogan, N.S., Currie, S., LeBlanc, S., Hewitt, L.M., MacLatchy, D.L., 2010. Modulation of steroidogenesis and estrogen signalling in the estuarine killifish (Fundulus heteroclitus) exposed to ethinylestradiol. Aquatic Toxicology 98, 148-156. 
Howe, C.M., Berrill, M., Pauli, B.D., Helbing, C.C., Werry, K., Veldhoen, N., 2004. Toxicity of glyphosate-based pesticides to four North American frog species. Environmental Toxicology and Chemistry 23, 1928-1938.

Johnson, P.,T.J., Dosch, K.L., Hartson, R.B., Gross, J.A., Larson, D.J., Sutherland, D.R., Carpenter, S.R., 2007. Aquatic eutrophication promotes pathogenic infection in amphibians. Proceedings of the National Academy of Sciences 104, 1578115786.

Jooste, A., du Preez, L.H., Carr, J.A., Giesy, J.P., Gross, T.S., Kendall, R.J., Smith, E.E., Van Der Kraak, G.L., Solomon, K.R., 2005. Gonadal development of larval male Xenopus laevis exposed to atrazine in outdoor microcosms. Environmental Science and Technology 39, 5255-5261.

Kiesecker, J.M., 2002. Synergism between trematode infection and pesticide exposure: a link to amphibian limb deformities in nature? Proceedings of the National Academy of Sciences of the United States of America 99, 9900-9904.

Kloas, W., Lutz, I., Springer, T., Krueger, H., Wolf, J., Holden, L., Hosmer, A., 2009. Does atrazine influence larval development and sexual differentiation in Xenopus laevis? Toxicological Sciences 107, 376-384.

Koprivnikar, J., Forbes, M.R., Baker, R.L., 2006. Effects of atrazine on cercarial longevity, activity, and infectivity. Journal of Parisitology 92, 306-311.

Koprivnikar, J., Forbes, M.R., Baker, R.L., 2007. Contaminant effects on host-parasite interactions: atrazine, frogs, and trematodes. Environmental Toxicology and Chemistry 26, 2166-2170.

LaFiandra, E.M., Babbitt, K.J., Sower, S.A., 2008. Effects of atrazine on anuran development are altered by the presence of a nonlethal predator. Journal of Toxicology and Environmental Health, Part A 71, 505-511.

Langlois, V.S., Carew, A.C., Pauli, B.D., 2010. Low levels of the herbicide atrazine alter sex ratios and reduce metamorphic success in Rana pipiens tadpoles raised in outdoor mesocosms. Environmental Health Perspectives 118, 552-557.

Lenkowski, J.R., Sanchez-Bravo, G., McLaughlin, K.A., 2010. Low concentrations of atrazine, glyphosate, 2,4-dichlorophenoxyacetic acid, and triadimefon exposures have diverse effects on Xenopus laevis organ morphogenesis. Journal of Environmental Sciences 22, 1305-1308.

Mackenzie, C.A., Berrill, M., Metcalfe, C., Pauli, B.D., 2003. Gonadal differentiation in frogs exposed to estrogenic and antiestrogenic compounds. Environmental Toxicology 22, 2466-2475.

Mann, R.M., Bidwell, J.R., 1999. The toxicity of glyphosate and several glyphosate formulations to four species of southwestern Australian frogs. Archives of Environmental Contaminants and Toxicology 36, 193-199.

Mann, R.M., Hyne, R.V., Choung, C.B., Wilson, S.P., 2009. Amphibians and agricultural chemicals: review of the risks in a complex environment. Environmental Pollution 157, 2903-2927.

Marcogliese, D.J., King, K.C., Salo, H.M., Fournier, M., Brousseau, P., Spear, P., Champoux, L., McLaughlin, J.D., Boily, M., 2009. Combined effects of agricultural activity and parasites on biomarkers in the bullfrog, Rana catasbeiana. Aquatic Toxicology 91, 126-134.

Martin, D.B., Hartman, W.A., 1984. Arsenic, cadmium, lead, mercury, and selenium in sediments of riverine and pothole wetlands of the north central United States. Journal of the Association of Analytical Chemistry 67, 1141-1146.

McCoy, K.A., Bortnick, L.J., Campbell, C.M., Hamlin, H.J., Guillette, L.J., St. Mary, C.M., 2008. Agriculture alters gonadal form and function in the toad Bufo marinus. Environmental Health Perspectives 116, 1526-1532.

McDaniel, T., Martin, P., Struger, J., Sherry, J., Marvin, C., McMaster, M., Clarence, S. Tetreault, G., 2008. Potential endocrine disruption of sexual development in free ranging male northern leopard frogs (Rana pipiens) and green frogs (Rana clamitans) from areas of intensive row crop agriculture. Aquatic Toxicology 90, 230-242.

McMurtrey, M.S., Craig, R., Schildman, G., 1972. Survey of Habitat: Work Plan K-71, P-R Project W-15-R-28. Nebraska Game and Parks Commission, Lincoln, NE.

Murphy, M.B., Hecker, M., Coady, K.K., Tompsett, A.R., Jones, P.D., Du Preez, H.L. Everson, G.J., Solomon, K.R., Carr, J.A., Smith, E.E., Kendall, R.J., Van Der Kraak, G., Giesy, J.P., 2006. Atrazine concentrations, gonadal gross morphology and histology in ranid frogs collected in Michigan agricultural areas. Aquatic Toxicology 76, 230-245

NASS (National Agricultural Statistics Service), 2005. Agricultural Chemical Usage 2004 Field Crops Summary. http://www.nass.usda.gov/Statistics_by_Subject/ Environmental/index.asp (last accessed 06.07.12.).

NASS (National Agricultural Statistics Service), 2006. Agricultural Chemical Usage 2005 Field Crops Summary. http://www.nass.usda.gov/Statistics_by_Subject/ Environmental/index.asp (last accessed 06.07.12.).

NASS (National Agricultural Statistics Service), 2011. Agricultural Chemical Usage 2006 Searchable Database. http://www.pestmanagement.info/nass/act_dsp_ statcs2_state.cfm (last accessed 06.07.12.).

NDEQ (Nebraska Department of Environmental Quality), 2009. Title 117, Chapter 4. Nebraska Department of Environmental Quality. Lincoln, NE. http://www.deq. state.ne.us/RuleAndR.nsf/pages/117-TOC (last accessed 06.07.12.).

Ogielska, M., Bartmanska, J., 1999. Development of testes and differentiation of germ cells in water frogs of the Rana esculenta - complex (Amphibia, Anura). Amphibia-Reptilia 20, 251-263.
Ogielska, M., Kotusz, A., 2004. Pattern and rate of ovary differentiation with reference to somatic development in anuran amphibians. Journal of Morphology $259,41-54$

Oka, T., Tooi, O., Mitsui, N., Miyahara, M., Ohnishi, Y., Takase, M., Kashiwagi, A. Shinkai, T., Santo, N., Iguchi, T., 2008. Effect of atrazine on metamorphosis and sexual differentiation in Xenopus laevis. Aquatic Toxicology 87, 215-226.

Orton, F., Carr, J.A., Handy, R.D., 2006. Effects of nitrate and atrazine on larval development and sexual differentiation in the northern leopard frog Rana pipiens. Environmental Toxicology and Chemistry 25, 65-71.

RWBJV (Rainwater Basin Joint Venture), 2012. Rainwater Basin Fact Sheet. http:// www.rwbjv.org/pdf/Rainwater_Basin_Fact_Sheet.pdf (last accessed 06.07.12.).

Relyea, R.A., 2005a. The impact of insecticides and herbicides on the biodiversity and productivity of aquatic communities. Ecological Applications 15, 618-627.

Relyea, R.A., 2005b. The lethal impacts of roundup and predatory stress on six species of North American tadpoles. Archives of Environmental Contamination and Toxicology 48, 351-357.

Relyea, R.A., 2005c. The lethal impact of roundup on aquatic and terrestrial amphibians. Ecological Applications 15, 1118-1124.

Relyea, R.A., 2005d. Pesticides and amphibians: the importance of community context. Ecological Applications 15, 1125-1134.

Richards, C.M., Nace, G.W., 1978. Gynogenetic and hormonal sex reversal used in tests of the XX-XY hypothesis of sex determination in Rana pipiens. Growth 42 319-331.

Robichaux, R., Harrington, L.M.B., 2009. Environmental conditions, irrigation reuse pits, and the need for restoration in the rainwater basin wetland complex Nebraska. Papers of the Applied Geography Conferences 32, 217-225.

Rohr, J.R., Schotthoefer, A.M., Raffel, T.R., Carrick, H.J., Halstead, N., Hoverman, J.T. Johnson, C.M., Johnson, L.B., Lieske, C., Piwoni, M.D., Schoff, P.K., Beasley, V.R. 2008. Agrochemicals increase trematode infections in a declining amphibian species. Nature 455, 1235-1239.

Schildman, G., Hurt, J., 1984. Update of Rainwater Basin Wetland Survey. In: Survey of Habitat Work Plan K-83. W-15-R-40. Nebraska Game and Parks Commission, Lincoln, NE.

Schwarz, M.S., Lydick, C.D., 2010. Assessment of Selenium and Atrazine Exposure and Effects to Wildlife at the North Platte National Wildlife Refuge, Scottsbluff, Nebraska. U.S. Fish and Wildlife Service, Division of EnvironmentalQuality Region 6, DEC ID: 200560003, FFS: 6N54, Grand Isle, NE. http://www.fws.gov/ mountain-prairie/contaminants/papers/documents SchwarzandLydick2010AssessmentofSeNorthPlatte.pdf (last accessed 06.07.12.).

Spolyarich, N., Hyne, R.V., Wilson, S.P., Palmer, C.G., Byrne, M., 2011. Morphologica abnormalities in frogs from a rice-growing region in NSW, Australia, with investigations into pesticide exposure. Environmental Monitoring and Assessment $173,397-407$

Spolyarich, N., Hyne, R., Wilson, S., Palmer, C., Byrne, M., 2010. Growth, development and sex ratios of spotted marsh frog (Limnodynastes tasmaniensis) larvae exposed to atrazine and a herbicide mixture. Chemosphere 78, 807-813.

Storrs-Méndez, S.I., Semlitsch, R.D., 2009. Intersex gonads in frogs: understanding the time course of natural development and role of endocrine disruptors. Journal of Experimental Zoology, Part B Molecular and Developmental Evolution 312B, 2-11.

Storrs, S.I., Semlitsch, R.D., 2008. Variation in somatic and ovarian development: predicting susceptibility of amphibians to estrogenic contaminants. General and Comparative Endocrinology 156, 524-530.

USFWS (U.S. Fish and Wildlife Service), 2007. Comprehensive Conservation Plan Rainwater Basin Wetland Management District. Kearney, NE. http://www.fws. gov/mountain-prairie/planning/ccp/ne/rwb/rwb.html (last accessed 06.07.12.).

USFWS (U.S. Fish and Wildlife Service), 2008. Abnormal Amphibian Survey Standard Operating Procedures. Washington. http://www.fws.gov/contaminants/ Amphibian/OtherSOPs.html (last accessed 06.07.12.).

USFWS (U.S. Fish and Wildlife Service), 2011. Rainwater Basin Wetland Basin Management District. General Information. http://www.fws.gov/rainwater (last accessed 06.07.12.)

USDOI (U.S. Department of the Interior), 1994. The Impact of Federal Programs on Wetlands. In: A Report to Congress by the Secretary of the Interior, Washington, vol. II. http://www.doi.gov/oepc/wetlands2/index.html (last accessed 06.07.12.)

USEPA (U. S. Environmental Protection Agency), 1993. Reregistration Eligibility Decision (RED) for Glyphosate. EPA 738-R-93-014. http://epa.gov/oppsrrd1/ REDs/old_reds/glyphosate.pdf (last accessed 06.07.12.).

Williams, B.K. Semlitsch, R.,2010. Larval responses of three midwestern anurans to chronic, low-dose exposures of four herbicides. Archives of Environmental Contaminants and Toxicology 58, 819-827.

Wilson, K. Hardy, I.C.W., 2002. Statistical analysis of sex ratios: an introduction. In: Hardy, I.C.W. (Ed.), Sex Ratios: Concepts and Research Methods. University Press, Cambridge, pp. 48-92.

Wolf, J.C., Lutz, I., Kloas, W., Springer, T.A., Holden, L.R., Krueger, H.O., Hosmer, A.J. 2010. Effects of 17 beta-estradiol exposure on Xenopus laevis gonadal histopathology. Environmental Toxicology and Chemistry 29, 1091-1105. 